\title{
Assistência da Equipe Multiprofissional no Pós-Óbito: uma Proposta de Grupo
}

\author{
Ferreira, Maria Flávia Frajácomo; Pinto, Bruna Teixeira; Lanza, Ana Luiza;
}

Bérgamo, Daniela Carvalho; Boni, Jaqueline Aparecida; Bombarda, Tatiana

Barbieri

Hospital Estadual Américo Brasiliense — brunateix@bol.com.br

INTRODUÇÃO a vivência do luto possui características próprias, podendo expressar-se em um profundo desânimo, diminuição ou perda do interesse pelo mundo externo e redução das atividades em geral. (Mendlowicz, 2000). Se constitui em um processo ativo, em que há "um esforço que exige lembrar para esquecer" (Silva, 2011, p. 712). Tem caráter universal, fazendo parte da vida de qualquer ser humano, ainda que se constitua em um plano particular, permeado pela subjetividade. (Souza e Corrêa, 2009). Apesar de ser uma experiência individual pode ser compartilhada à medida que os conteúdos emocionais podem ser expressados, principalmente através da palavra. Exprimir a perda através do discurso possibilita a organização mental da vivência e assim, compreendê-la para elaborá-la. OBJETIVOS o Grupo de Acolhimento ao Luto visa prevenir a instauração do luto patológico através da oferta de um espaço livre de expressão cujas intervenções realizadas são focadas no auxílio ao enfrentamento do processo da perda. MÉTODOS o grupo tem caráter aberto, voltado aos familiares de usuários que vieram a óbito na instituição. Ocorre em data fixa, uma vez ao mês, com duração de 1 hora. Não há limite de participantes para a sua realização e o mesmo é coordenado por uma terapeuta ocupacional e uma psicóloga. Os familiares são convidados a participar do grupo através de contato telefônico (após 30 dias do óbito) e envio de carta (após 60 dias do óbito) ofertando condolências e contendo o cronograma dos encontros. o grupo se constitui em roda, sendo trabalhados conteúdos a partir de verbalizações espontâneas dos participantes. Os profissionais assumem a mediação das expressões, realizando intervenções de acordo com as demandas emergidas. RESULTADOS o grupo acontece há 2 anos, sendo que em 2013, ocorreram 267 óbitos na instituição, 9 encontros e um total de 40 participantes. nos meses de Janeiro, Fevereiro e Outubro o grupo não aconteceu por ausência de participantes. CONCLUSÕES a proposta do grupo favorece a co-responsabilização da instituição diante da demanda do luto, garantindo a continuidade da assistência após a ocorrência do óbito e, quando necessária, a articulação com demais especialidades da instituição ou com os serviços da rede básica de saúde. a ação vincula-se às diretrizes de acolhimento e clínica ampliada da Política Nacional de Humanização, ofertando uma escuta qualificada, contribuindo para uma visão integral do sujeito através de intervenções multiprofissionais. Levando-se em conta a complexidade do tema abordado pelo grupo, sendo o retorno ao local de falecimento, a expressão e o compartilhamento da vivência fatores geradores de sofrimento, considera-se esperada a oscilação do número de participantes, bem como as dificuldades de manutenção temporal do vínculo destes com o espaço proposto, necessitando o monitoramento constante de sua estrutura.

Ferreira, Maria Flávia Frajácomo; Pinto, Bruna Teixeira; Lanza, Ana Luiza; Bérgamo, Daniela Carvalho; Boni, Jaqueline Aparecida; Bombarda, Tatiana Barbieri. Assistência da Equipe Multiprofissional no Pós-Óbito: uma Proposta de Grupo. In: Anais do Congresso Internacional de Humanidades \& Humanização em Saúde [= Blucher Medical Proceedings, num.2, vol.1]. São Paulo: Editora Blucher, 2014. ISSN 2357-7282

DOI 10.5151/medpro-cihhs-10508 